\title{
PENGARUH CORPORATE GOVERNANCE TERHADAP KINERJA PERUSAHAAN GUDANG GARAM
}

\author{
Alisa Jihan Siffiana ${ }^{1}$, Winda Septiana ${ }^{2}$, Kharis Fadlullah Hana ${ }^{3}$ \\ ${ }^{1}$ Mahasiswa Ekonomi Syariah, Fakultas Ekonomi dan Bisnis Islam, IAIN Kudus \\ ${ }^{2}$ Mahasiswa Ekonomi Syariah, Fakultas Ekonomi dan Bisnis Islam, IAIN Kudus \\ ${ }^{3}$ Dosen Ekonomi Syariah, Fakultas Ekonomi dan Bisnis Islam, IAIN Kudus \\ Email: alisabeaj@gmail.com,windaseptianaaa@gmail.com,kharis@iainkudus.ac.id
}

\begin{abstract}
ABSTRAK
Tata kelola perusahaan adalah rangkaian proses, kebiasaan, kebijakan, aturan dan institusi yang mempengaruhi pengarahan, pengelolaan, serta pengontrolan suatu perusahaan atau korporasi. Penelitian ini bertujuan untuk menguji kembali apakah terdapat pengaruh corporate governance terhadap kinerja perusahaan. Penelitian ini menggunakan metode penelitian kuantitatif deskriptif, dengan menggunakan data sekunder berupa laporan keuangan per kuartal tahun 2015-2019 pada Perusahaan Gudang Garam Tbk, serta dilakukan pengujian analisis regresi linier berganda yang diukur dengan proporsi komisaris independen, komite audit, kepemilikan manajerial, kepemilikan institusional terhadap Return On Assets. Hal itu dapat dilihat pada uji asumsi klasik terdiri dari uji normalitas, uji autokorelasi, dan uji heterokedastisitas. Hasil penelitian menunjukkan bahwa uji normalitas dan uji autokorelasi terdapat pengaruh terhadap kinerja perusahaan, sedangkan uji heterokedastisitas tidak terjadi pengaruh terhadap kinerja perusahaan. Analisis uji t parsial diperoleh hasil bahwa corporate governance berpengaruh terhadap kinerja perusahaan. Hasil analisis uji $f$ simultan diperoleh hasil bahwa corporate governance berpengaruh terhadap kinerja perusahaan. Kata Kunci: Corporate Governance, Kinerja Perusahaan, Return On Assets.
\end{abstract}

\begin{abstract}
Corporate governance is a series of processes, habits, policies, rules and institutions that affect the direction, management, and control of a compny or corporation. This study aims to reexamine whether there is an influence of corporate governance on cmpany performance. This research uses descriptive quantitative research methods, using secondary data in the form of financial reports per quarter 2015-2019 at Gudang Garam Tbk Company, as well as testing multiple linear regression analysis measured by the propotion of independen commissioners, audit committees, managerial ownership, institutional ownership of Return On Assets. This can be seen in the classical asumption test consisting of normality test, autocorrelation test, and heterokedasticity test. The results showed that the normality test and the autocorrelation test had an influence on company performance, while the heteroskedasticity test did not affect the company's performance. The partial t-test analisys showed that corporate governance has an effect on company performance. The result of the simultaneous $f$ test analisys showed that corporate governance influences company performance.
\end{abstract}

Keywords: Coporate Governance, Company Performance, Return On Assets. 


\section{A. PENDAHULUAN}

Dewasa ini, kondisi ekonomi yang berkembang banyak memberikan perubahan perekonomian nasional terutama semakin ketatnya dunia persaingan bisnis, hal ini dapat dilihat dari para pelaku ekonomi baik lokal maupun asing yang tidak ragu untuk mendirikan bisnisnya di Indonesia (Muchtar, 2013). Perkembangan dunia bisnis tersebut tentunya didukung oleh ide kreatif dari para pelaku usaha yang bermunculan. Para pelaku usaha dituntut untuk dapat melihat peluang bisnis dengan baik sehingga dapat menarik perhatian para konsumennya (Nofitasari, 2015). Untuk itu, setiap perusahaan harus cerdas dalam menjalankan usahanya demi kesejahteraan hidup di masa mendatang. Perusahaan yang tidak dapat bersaing akan mengalami kegagalan atau gulung tikar sehingga memerlukan adanya pengelolaan perusahaan yang baik. Dengan demikian, para investor akan lebih tertarik perusahaan yang memiliki tata kelola baik daripada tata kelola yang tidak baik dalam menanamkan modalnya.

Tata kelola perusahaan bisa dilihat dari kinerja keuangannya. Apalagi kinerja keuangan bisa dijadikan tolak ukur keberhasilan pihak manajemen dalam mencapai laba perusahaan. Hal ini dapat dianalisis dan dilihat dari informasi yang sudah ditampilkan dalam laporan keuangan. Laporan keuangan adalah salah satu bahan rekomendasi bagi investor untuk bertindak, karena laporan keuangan mencerminkan kondisi fundamental keuangan perusahaan (Tommy Gunawan, 2018). Namun, saat ini terjadi persoalan mengenai tata kelola perusahaan seiring dengan terbukanya masalah keuangan yang terjadi tahun 2006, hingga sampai sekarang tidak kunjung menemukan jalan keluar. Masalah tersebut melibatkan manipulasi laporan keuangan oleh PT Asuransi Jiwasraya. Pada kenyataannya sejak tahun 2006 perusahaan masih membukukan laba, tetapi sebenarnya laba tersebut adalah laba semu dari rekayasa akuntansi atau window dressing di mana perusahaan tersebut sebenarnya sudah mengalami kerugian. Manipulasi ini terekspos setelah Badan Pemeriksa Keuangan (BPK) melakukan investigasi pendahuluan yang dilakukan sejak 2018. Hasil pemeriksaan investigasi menunjukkan adanya penyimpanganpenyimpangan yang berindikasi fraud (penipuan) dalam pengelolaan saving plan dan investasi. Pada 2018, BPK menemukan bahwa Jiwasraya membukukan kerugian sebesar Rp 15,3 triliun, berdasarkan temuan hingga September 2019 indikasi kerugian Rp 13,7 triliun. Pada November 2019 diperkirakan mengalami negative equity (kewajiban lebih besar dari aset) sebesar 27,2 triliun. Adanya fenomena mengenai manipulasi laporan keuangan oleh PT Asuransi Jiwasraya merupakan suatu kegagalan mengenai laporan keuangan dalam memenuhi informasi bagi pengguna laporan yang diakibatkan dari kurangnya penerapan good corporate governance (GCG) oleh perusahaan tersebut. 
Beberapa penelitian telah dilakukan mengenai tata kelola perusahaan (corporate governance) terhadap kinerja perusahaan, di mana para peneliti mempunyai anggapan masing-masing terkait penelitian. Penelitian dari Sani Kustiani, dkk menemukan bahwa secara parsial good corporate governance berpengaruh terhadap kinerja keuangan PT Gudang Garam Tbk periode 2007-2017, tingkat hubungan yang dimiliki termasuk dalam kategori hubungan sangat kuat dan bernilai positif. Oleh sebab itu, meningkatnya good corporate governance maka kinerja keuangan tersebut juga akan meningkat (Kustiani et al., 2019). Nunung Nofitasari, dkk menemukan bahwa hasil secara parsial berupa good corporate governance tidak berpengaruh terhadap nilai perusahaan, sedangkan kinerja perusahaan berpengaruh terhadap nilai perusahaan. Secara simultan, diperoleh hasil bahwa good corporate governance dan kinerja perusahaan berpengaruh terhadap nilai perusahaan (Nofitasari, 2015). Penelitian yang dilakukan Fifi Nofianti dan Poppy Nurmayanti menemukan bahwa corporate governance berpengaruh terhadap ROE, NPM, dan Tobins' $Q$ secara positif dan signifikan. Hal ini membuktikan bahwa perusahaan menerapkan tata kelola perusahaan yang baik, maka tingkat pengembalian investasi, penjualan serta kinerja perusahaan akan meningkat. Dan hasilnya banyak investor yang akan menanamkan modalnya pada perusahaan tersebut. Dengan demikian corporate governance mempengaruhi kinerja perusahaan (Nofiani et al.,, 2010). Melia
Agustina Tertius, dkk mengemukakan bahwa secara simultan yang mempengaruhi ROA itu dewan komisaris, komisaris independen, kepemilikan manajerial, dan ukuran perusahaan. Secara parsial, yang tidak mempengaruhi ROA itu dewan komisaris dan kepemilikan manajerial. Sedangkan yang berpengaruh negatif dan signifikan terhadap ROA itu komisaris independen dan ukuran perusahaan (Melia, et al., 2015).

Berdasarkan beberapa penelitian tersebut menunjukkan hasil bahwa corporate governance memang berpengaruh terhadap kinerja perusahaan seperti berpengaruh pada kinerja keuangannya, nilai perusahaan, maupun berpengaruh pada ROA, REO, NPM, dan Tobin's. Namun terdapat diferensiasi yang menyatakan mekanisme internalcorporate governance tidak begitu mempengaruhi kinerja perusahaan. Untuk itu penelitian ini bertujuan untuk menguji kembali apakah terdapat pengaruh corporate governance terhadap kinerja perusahaan pada bagian keuangan.

\section{Agency Theory}

Berawal dari agency theory yang dikemukakan oleh Means dan Berle (1932) kemudian teori tersebut dikembangkan oleh Jensen dan Meckling (1976) menyatakan bahwa terdapat hubungan kerja dari pihak yang memberi wewenang (principal) dengan yang menerima wewenang (agent) dalam bentuk kontrak kerja yang telah disepakati (Darman, 2015). Menurut Scott (2003) agency theory merupakan suatu perjanjian untuk memotivasi 
agen dalam bertindak atas nama pemiliknya begitu pula sebaliknya dapat bertentangan dengan kepentingan pemilik. Setiap pihak yang terlibat dalam perjanjian selalu berusaha untuk mendapatkan yang terbaik bagi dirinya sendiri, Hubungan agen dengan pemilik terjadi ketika pelaku menyewa agen untuk mendelegasikan tugas atas nama pemilik (Melia Agustina Tertius dan Yulius Jogi Christiawan, SE., M.Si, 2015). Menurut Darmawati, dkk (2004) inti dari hubungan keagenan yaitu terjadinya pemisahan antara kepemilikan (principal) dan pengendalian (agent) (Darwis, 2009). Elisanhardt (1989) mengungkapkan bahwa teori agensi menggunakan tiga asumsi sifat manusia terdiri dari manusia pada umumnya lebih mementingkan diri sendiri (self interest), manusia memiliki daya pikir terbatas mengenai persepsi masa mendatang (bounded rationality) dan manusia selalu menghindari risiko yang terjadi (risk averse). Berdasarkan asumsi tersebut, manusia sebagai agen akan bertindak dengan lebih mengutamakan kepentingan pribadinya (RB. Wiyarsi, 2012).

\section{Definisi Kinerja}

Kinerja merupakan konstruk multifacted, pihak-pihak yang berkepentingan terhadap kinerja cenderung mendefinisikan kinerja sesuai dengan pemahaman dan kepentingannya. Untuk memahami pengertian kinerja, terlebih dahulu memahami arti kinerja secara harfiah. Kata kinerja dalam Bahasa Inggris yaitu performance (noun-kata benda). Performance diterjemahkan ke dalam Bahasa Indonesia menggunakan kamus yang sama, atau kamus inggris-indonesia lain misalnya yang ditulis Echols dan Shadily (1998), hasilnya bukan kinerja melainkan: pertunjukan, pekerjaan, perbuatan, hasil. Dengan demikian secara sistematis, dapat disimpulkan bahwa kinerja pengertiannya sama dengan pertunjukan, pekerjaan, perbuatan, hasil. Armstrong dan Baron (2005), mengemukakan bahwa kinerja merupakan sesuatu yang telah dicapai oleh seseorang atau suatu organisasi. Disisi lain Brumback (1988) mendefinisikan kinerja sebagai akumulasi perilaku dan hasil. Dalam penilaian kerja yang dinilai bukan hanya hasilnya, tetapi juga pe rilaku yang dilakukan. Penyebabnya karena perilaku itu sendiri sesungguhnya adalah sebuah produk. Menurut Brumback, perilaku adalah hasil dari upaya mental dan fisik seseorang yang timbul selama proses aktivitas berlangsung (Sobirin, 2014).

\section{Definisi Corporate Governance}

Menurut FCGI (2001) good corporate governance merupakan seperangkat aturanaturan yang mengatur hubungan antara pemegang saham, pengelola perusahaan, pemerintah, pihak kreditur, karyawan serta para pemegang kepentingan intern dan ekstem lainnya yang berkaitan dengan hak serta kewajiban, dengan kata lain suatu sistem yang mengatur dan mengendalikan perusahaan. Menurut Rahmawati (2006) dalam Putri (2006) good corporate governance adalah seperangkat aturan dan prinsip yang terdiri dari transparancy, fairness, responsibility dan 
accountability, yang mengatur hubungan antara pemegang saham, manajemen, perusahaan (direksi dan komisaris), kreditur, karyawan serta stakeholder lainnya yang berkaitan dengan hak dan kewajiban setiap pihak. Berdasarkan definisi-definisi tersebut disimpulkan bahwa, pada dasarnya good corporate governance yaitu suatu proses, sistem, dan seperangkat aturan yang mengatur hubungan antara berbagai pihak yang berkepentingan (stakeholder) terutama para pemegang saham, dewan komisaris, dan dewan direksi demi tercapainya tujuan perusahaan (M. Nasrum, n.d.).

\section{B. METODE}

\section{Jenis Penelitian}

Penelitian ini akan menguji kembali apakah terdapat pengaruh corporate governance terhadap kinerja perusahaan. Penelitian ini menggunakan metode penelitian kuantitatif deskriptif dengan menggunakan metode purposive sampling karena dalam pengambilan sampling memiliki tujuan yaitu mengambil sampel yang memiliki kinerja sebagai berikut:

a. Perusahaan yang dijadikan sampel adalah industri rokok yang sudah terdaftar di Bursa Efek Indonesia.

b. Salah satu perusahaan rokok terdaftar di Bursa Efek Indonesia selama periode pengamatan dari tahun 2015 sampai 2019.

c. Memiliki laporan keuangan yang lengkap sesuai dengan kebutuhan variabel dalam penelitian ini.

\section{Jenis Data}

Jenis data yang digunakan dalam penelitian ini adalah data sekunder berupa laporan keuangan per kuartal dan catatan atas laporan keuangan selama 2015-2019. Data-data penelitian tersebut diperoleh dari website resmi Bursa Efek Indonesia yaitu www.idx.co.id dan juga website resmi Perusahaan Gudang Garam Tbk. www.gudanggaramtbk.com, data-data kedua website tersebut diunduh pada 08 April 2020, pukul 13.30 WIB.

\section{Populasi dan Sampel}

Adapun populasi yang digunakan yaitu dari perusahaan industri rokok yang terdaftar di BEI. Sampel yang digunakan adalah perusahaan Gudang Garam yang sudah menerapkan corporate governance dan perusahaan ini juga memiliki peran penting dalam perekonomian Indonesia.

\section{Alat Analisis}

Penelitian ini menggunakan analisis regresi linier berganda dengan model analisis:

$R O A=\alpha+B_{1}$ Kom.Ind $+B_{2}$ Komite + $B_{3}$ Kep.Man $+B_{4}$ Kep.Ins $+e$

Keterangan:

ROA : Return on Asset

a : konstanta

$\mathrm{B}_{1} \quad$ : koefisien

Kom.Ind : Komisaris Independen

Komite : Komite Audit

Kep.Man : Kepemilikan Manajerial

Kep.Ins : Kepemilikan Institusional

e $\quad$ : residu/eror 
Adapun variabel dependen penelitian ini yaitu kinerja perusahaan yang diukur dengan Return On Assets (ROA).

$R O A=\frac{\text { LabaBersih setelahpajak }}{\text { Total aset }}$

Serta variabel Independen terdiri dari:

a. Komisaris independen diukur dengan pembagian sebagai berikut:

Komisaris idp. $=\frac{\text { jumlah } k o m i s a r i s i n d e p e n d e n}{\text { jumlah } \text { komisaris }}$.

b. Komite audit diukur melalui jumlah komite audit yang diperoleh dari catatan atas laporan keuangan.

c. Kepemilikan manajerial diukur dengan membagi jumlah saham manajemen dengan jumlah saham beredar.

Kep. manajerial $=\frac{\text { jumlah sahamimanajemen }}{\text { jumlah sahamberedar }}$.

d. Kepemilikan institusional diukur dengan membagi jumlah saham yang dimiliki institusional dengan jumlah saham beredar.

Kep.institusional $=\frac{\text { jumlah } \text { saham institusional }}{\text { jumlah saham beredar }}$

\section{HASIL DAN PEMBAHASAN}

\section{Uji Asumsi Klasik}

\section{Statistik Deskriptif}

Statistik deskriptif untuk variabel independen dan dependen. Di mana variabel independen berupa good corporate governance yang diukur dengan proporsi dewan komisaris independen (X1), komite audit (X2), kepemilikan manajerial (X3) dan kepemilikan institusional (X4). Variabel dependen yaitu kinerja perusahaan yang diukur dengan menggunakan Return On Assets (ROA) sebagaiY.

Tabel 1. Statistik Deskriptif

\begin{tabular}{cccc}
\hline \multicolumn{4}{c}{ Descriptive Statistics } \\
\hline & Mean & Std. Deviation & N \\
\hline Y & .0690 & .03495 & 20 \\
\hline X1 & .5000 & .00000 & 20 \\
\hline X2 & 3.00 & .000 & 20 \\
\hline X3 & .0692 & .00102 & 20 \\
\hline X4 & .0920 & .00000 & 20
\end{tabular}

Sumber: Hasil Pengolahan Data (2020)

Berdasarkan tabel 1. output SPSS dapat diketahui bahwa mean/nilai rata-rata pada variabel Y (ROA) sebesar 0,0690, nilai rata-rata variabel X1 (Komisaris Independen) sebesar 0,5000, nilai rata-rata variabelX2 (Komite Audit) sebesar 3,00, nilai rata-rata variabel X3 (Kepemilikan Manajerial) sebesar 0,0692, sedangkan nilai rata-rata variabel $\mathrm{X} 4$ (Kepemilikan Institusional) sebesar 0,0920. Standar deviation, menyatakan simpangan baku, yakni akar dari variasi, dalam kasus ini nilai simpangan baku pada variabel Y (ROA) adalah 0,03495, pada variabel X1 (Komisaris Independen) adalah 0,0000, pada variabel X2 (Komite Audit) adalah 0,000, pada variabel X3 Kepemilikan Manajerial) adalah 0,00102, sedangkan pada variabel X4 (Kepemilikan Institusional) adalah 0,00000. N menyatakan jumlah data, jumlah data yang diperoleh dari variabel $Y$ (ROA), variabel $\mathrm{X} 1$ (Komisaris Independen), variabel X2 (Komite Audit), variabelX3 (Kepemilikan Manajerial), variabel X4 (Kepemilikan Institusional) adalah sebanyak 20 data. Selanjutnya untuk membuktikan terdapat pengaruh yang signifikan atau tidak, diperlukan 
pengujian melalui uji normalitas, uji heteroskedastisitas dan ujiautokorelasi.

\section{Uji Normalitas}

Uji normalitas berguna untuk menentukan data yang telah dikumpulkan berdistribusi normal sebab banyaknya data yang kurang dari tiga puluh bisa dipastikan berdistribusi normal dan sebaliknya untuk itu perlu suatu pembuktian (Basuki, 2016). Sedangkan diagram Normal P-P Plot, dikatakan memenuhi asumsi normalitas, jika plot-plot mengikuti alur garis lurus atau mengikutigaris diagonalnya (Hidayat, 2013).

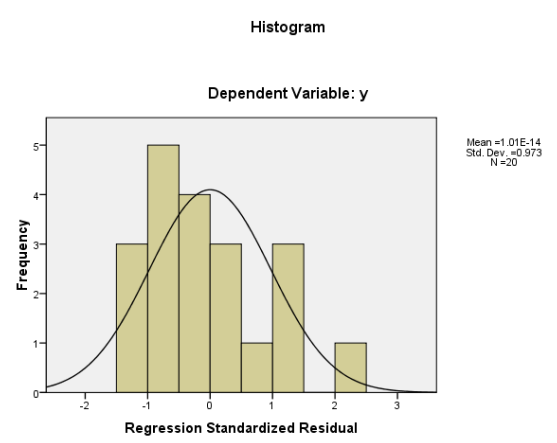

Gambar 1. Histogram

Sumber: Hasil Pengolahan Data (2020)

Berdasarkan gambar grafik histogram di atas menunjukkan grafik yang simetris, yang artinya model regresi memiliki pola yang berdistribusinormal.

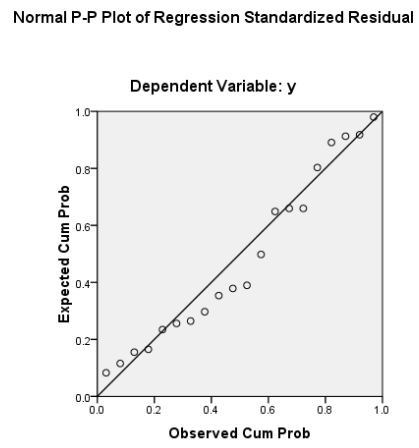

Gambar 2. Uji Normalitas Probability Plot Sumber: Hasil Pengolahan Data (2020)
Berdasarkan gambar output SPSS Uji normalitas probability plot di atas, diketahui bahwa titik-titik pada gambar menyebar sekitar garis dan mengikuti garis diagonal maka nilai residual tersebut berdistribusi normal.

\section{Uji Heteroskedastisitas}

Kriteria pengambilan keputusan yaitu:

a. Jika ada pola tertentu, seperti titik-titik yang ada membentuk suatu pola tertentu yang teratur (bergelombang, melebar kemudian menyempit) maka terjadi heteroskedastisitas.

b. Jika tidak ada pola yang jelas seperti titiktitik menyebar diatas dan di bawah angka 0 pada sumbu $\mathrm{Y}$, maka tidak terjadi heteroskedastisitas (Purnomo, 2017).

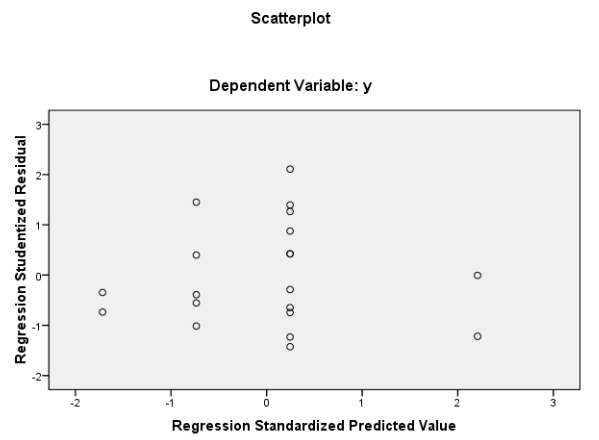

Gambar 3. Uji Heteroskedastisitas Scatterplot Sumber: Hasil Pengolahan Data (2020)

Berdasarkan gambar output SPSS uji heteroskedastisitas diketahui bahwa titik-titik pada gambar tidak membentuk pola tertentu dan titik menyebar diatas dan di bawah angka 0 pada sumbu $Y$, maka dapat disimpulkan tidak terjadi gangguan asumsi heteroskedastisitas.

\section{Matriks Koefisien Korelasi}

Matriks koefisien korelasi juga didapat dari ststistik deskriptif. Sehingga dapat melihat data 
koefisien korelasi antar semua variabel tanpa terkecuali (Kusnadi, 2009).

Tabel 2. Correlation

\begin{tabular}{|c|c|c|c|c|c|c|}
\hline \multicolumn{7}{|c|}{ Correlations } \\
\hline & & y & $\mathbf{x 1}$ & $x 2$ & $x 3$ & $\mathbf{x 4}$ \\
\hline \multirow{9}{*}{$\begin{array}{c}\text { Pearson } \\
\text { Correlatio } \\
n\end{array}$} & $y$ & 1.00 & $\theta^{\circ}$ & & - & . \\
\hline & & 0 & & & .469 & \\
\hline & $x 1$ & . & 1.00 & & & . \\
\hline & & & 0 & & & \\
\hline & $x 2$ & . & & 1.00 & & . \\
\hline & & & & c & & \\
\hline & x3 & - & & & 1.00 & \\
\hline & & .469 & & & 0 & \\
\hline & $\mathrm{x4}$ & . & & & & 1.00 \\
\hline \multirow{5}{*}{$\begin{array}{l}\text { Sig. (1- } \\
\text { tailed) }\end{array}$} & $y$ & & .000 & .000 & .018 & .000 \\
\hline & $x 1$ & .000 & & .000 & .000 & .000 \\
\hline & $x 2$ & .000 & .000 & & .000 & .000 \\
\hline & $x 3$ & .018 & .000 & .000 & . & .000 \\
\hline & $x 4$ & .000 & .000 & .000 & .000 & . \\
\hline \multirow[t]{5}{*}{$\mathbf{N}$} & $y$ & 20 & 20 & 20 & 20 & 20 \\
\hline & $x 1$ & 20 & 20 & 20 & 20 & 20 \\
\hline & $x 2$ & 20 & 20 & 20 & 20 & 20 \\
\hline & $x 3$ & 20 & 20 & 20 & 20 & 20 \\
\hline & $x 4$ & 20 & 20 & 20 & 20 & 20 \\
\hline
\end{tabular}

Sumber: Hasil Pengolahan Data (2020)

Berdasarkan tabel 2 . output SPSS matriks korelasi dapat diketahui angka signifikansi untuk hubungan antar seluruh variabel independen dengan variabel dependen bernilai di bawah 0,05 atau $<0,05$, sehingga disimpulkan memang terdapat hubungan yang signifikan antara semua variabel independen terhadap variabel dependen. Penafsiran tersebut berpedoman pada nilai signifikansi 0,05 , sehingga bila nilainya < Sig. 0,05 maka terdapat hubungan yang signifikan.

\section{Uji Autokorelasi}

Model regresi yang baik seharusnya tidak terjadi autokorelasi. Pengujian menggunakan uji durbin watson. Pengambilan keputusan pada uji durbin watson sebagai berikut:

a. $\quad$ DU $<$ DW $<4$-DU maka Ho diterima, artinya tidak terjadi autokorelasi.

b. DW $<$ DL atau DW > 4-DL, maka Ho ditolak, artinya terjadi autokorelasi.

c. $\mathrm{DL}<\mathrm{DW}<\mathrm{DU}$ atau 4-DU $<\mathrm{DW}<4-\mathrm{DL}$, artinya tidak ada kepastian atau kesimpulan yang pasti.

Nilai DU dan DL dapat diperoleh dari tabel startistik Durbin Watson (Purnomo, 2017).

Tabel 3. ModelSummary

\begin{tabular}{cccccc}
\hline \multicolumn{7}{c}{ Model Summary } \\
\hline Model & $\mathbf{R}$ & R Square & $\begin{array}{c}\text { Adjusted R } \\
\text { Square }\end{array}$ & $\begin{array}{c}\text { Std. Error of } \\
\text { the Estimate }\end{array}$ & $\begin{array}{c}\text { Durbin- } \\
\text { Watson }\end{array}$ \\
\hline $\mathbf{1}$ & $.469 a$ & .220 & .177 & .03170 & 1.724 \\
\hline
\end{tabular}

a. Predictors: (Constant), x3

b. Dependent Variable: y

Sumber: Hasil Pengolahan Data (2020)

Berdasarkan tabel 3. output SPSS, diketahui nilai DU dicari pada distribusi nilai tabel durbin watson dengan nilai $k$ (1) dan $N(20)$ serta signifikansi 5\%. DU $(1,411)$ < Durbin Watson $(1,724)<4$-DU $(2,589)$. Jadi dapat disimpilkan bahwa nilai durbin watson terletak diantara DU dan 4-DU maka dapat dikatakan tidak terjadi autokorelasi pada model regresi. Berpedoman pada dasar pengambilan keputusan uji durbin watson maka $\mathrm{HO}$ diterima.

\section{Uji F Simultan Berdasarkan Nilai Signifikansi}

a. Jika nilai Sig. $<0,05$, maka variabel $X$ secara simultan berpengaruh terhadap variabelY. 
b. Jika nilai Sig. $>0,05$, maka variabel $\mathrm{X}$ secara simultan tidak berpengaruh terhadap variabel Y (Raharjo, 2016).

Tabel 4. Hasil Uji f

\begin{tabular}{ccccccc}
\hline \multicolumn{7}{c}{ ANOVA } \\
\hline & Model & Sum of Squares & df & Mean & F & Sig \\
& & & Square & & $\cdot$ \\
\hline 1 & $\begin{array}{c}\text { Regressi } \\
\text { on }\end{array}$ & .005 & 1 & .005 & 5. & .0 \\
& & & & 08 & 37 \\
& & & & 8 & $a$ \\
\hline Residual & .018 & 18 & .001 & & \\
\hline Total & .023 & 19 & & &
\end{tabular}

a. Predictors: (Constant), $\mathbf{x} 3$

b. Dependent Variable: $y$

Sumber: Hasil Pengolahan Data (2020)

Berdasarkan tabel output SPSS di atas, diketahui nilai Sig. sebesar 0,037. Karena nilai sig. 0,037<0,05, maka sesuai dengan dasar pegambilan keputusan dalam uji $\mathrm{F}$ variabel $\mathrm{X} 3$ secara simultan berpengaruh terhadap Y.

\section{Uji T Parsial Berdasarkan Nilai Signifikansi}

a. Jika nilai signifikansi (Sig.) < probabilitas 0,05 maka ada pengaruh variabel $X$ terhadap variabel $\mathrm{Y}$.

b. Jika nilai signifikansi (Sig.) > probabilitas 0,05 maka tidak ada pengaruh variabel $X$ terhadap variabel Y (Raharjo, 2014).

Tabel 5. Hasil Uji t

\begin{tabular}{|c|c|c|c|c|}
\hline \multicolumn{5}{|c|}{ Coefficients } \\
\hline \multirow[t]{3}{*}{ Model } & \multicolumn{2}{|c|}{$\begin{array}{l}\text { Unstandardized } \\
\text { Coefficients }\end{array}$} & \multirow{3}{*}{$\begin{array}{c}\text { Standardized } \\
\text { Coefficients } \\
\text { Beta }\end{array}$} & \multirow[t]{3}{*}{$\mathbf{t}$} \\
\hline & B & Std. & & \\
\hline & & Error & & \\
\hline 1 (Const & 1.183 & .494 & & 2.395 \\
\hline$x 3$ & -16.090 & 7.133 & -.469 & -2.256 \\
\hline
\end{tabular}

$$
\text { a. Dependent Variable: }
$$

$$
\text { y }
$$

Sumber: Hasil Pengolahan Data (2020)

Hipotesis yang digunakan untuk pengujian $\mathrm{t}$ parsial yaitu:

a. H1 menyatakan bahwa terdapat pengaruh yang positif dan signifikan X1 (komisaris independen)terhadap Y(ROA).

b. H2 menyatakan bahwa terdapat pengaruh yang positif dan signifikan $\mathrm{X} 2$ (komite audit) terhadap Y (ROA).

c. H3 menyatakan bahwa terdapat pengaruh yang positif dan signifikan X3 (kepemilikan manajerial) terhadap $Y$ (ROA). Hasil pengujian untuk variabel $X 3$ menunjukkan nilai signifikansi X3 (Kepemilikan Manajerial) sebesar 0,037. Karena nilai Sig. $0,037<0,05$ maka disimpulkan bahwa tidak ada pengaruh $\mathrm{X} 3$ terhadap $\mathrm{Y}$, yang menyatakan hipotesis $\mathrm{H} 3$ diterima.

d. H4 menyatakan bahwa terdapat pengaruh yang positif dan signifikan X4 (kepemilikan institusional) terhadap $Y(R O A)$.

Berdasarkan hasil pengujian, penelitian ini sejalan dengan penelitian yang telah dilakukan oleh Kustiani dkk (2019) di mana good corporate governance memiliki pengaruh signifikan sterhadap kinerja keuangan PT. Gudang Garam Tbk periode 2007-2017, dengan tingkat hubungan yang dimiliki termasuk dalam kategori d2gbungan bernilai positif dan sangat kuat. Oleh karena itu, bila good corporate governance mengalami suatu peningkatan maka kinerja keuangan perusahaan tersebut juga akan terjadi 
peningkatan. Tetapi hal ini tidak sejalan dengan penelitian Melia Agustina dan Yulius (2015) yang menyatakan secara parsial, dewan komisaris dan kepemilikan manajerial tidak berpengaruh terhadap ROA. Sedangkan, komisaris independen dan ukuran perusahaan berpengaruh secara negatif dan signifikan terhadap ROA.

\section{PENUTUP}

\section{Kesimpulan}

Berdasarkan hasil analisis dan pembahasan yang telah dilakukan mengenai pengaruh corporate goveranance terhadap kinerja Perusahaan Gudang Garam yang diukur dengan proporsi komisaris independen, komite audit, kepemilikan manajerial, kepemilikan institusional terhadap Return On Assets. Hal ini dilihat pada uji asumsi klasik yang terdiri dari uji normalitas, uji autokorelasi, dan uji heterokedastisitas. Hasil penelitian menunjukkan bahwa tidak adanya penyimpangan pada variabel atas uji asumsi klasik. Artinya variabel dan data yang tersedia telah memenuhi pedoman dalam penggunaan model persamaan regresi linier berganda. Pada uji normalitas histogram menunjukkan grafik yang simetris dan uji normalitas probability plot juga menunjukkan titik-titik menyebar mengikuti garis diagonalnya maka dinyatakan nilai berdistribusinormal dan berpengaruh pada kinerja perusahaan. Pada uji heteroskedastisitas menunjukkan tidak terjadinya gangguan asumsi heteroskedastisitas sehingga tidak terjadi pengaruh pada kinerja perusahaan. Pada matriks koefisien korelasi menyatakan terdapat hubungan yang signifikan antara semua variabel independen terhadap variabel dependen. Pada uji autokorelasi nilai Durbin Watson tidak terjadi autokorelasi artinya $\mathrm{HO}$ diterima, sehingga uji autokorelasi berpengaruh pada kinerja perusahaan. Berdasarkan analisis uji t parsial diperoleh hasil berupa secara parsial variabel $X$ berpengaruh positif terhadap $Y$ yang berarti corporate governance berpengaruh terhadap kinerja perusahaan. Hasil analisis uji $f$ simultan diperoleh hasil bahwa variabel X secara simultan berpengaruh terhadap $Y$ atau corporate governance berpengaruh terhadap kinerja perusahaan.

\section{Saran}

Saran yang dapat diberikan peneliti pada penelitian ini adalah sebagai berikut:

a. Perusahaan sebaiknya mengaplikasikan corporate governance dengan baik, agar kinerja perusahaan dapat ditingkatkan.

b. Perusahaan sebaiknya memperbaharui informasi mengenai perusahaan dibidang kinerja keuangan sehingga calon investor akan mudah memperoleh informasi mengenai perusahaan.

c. Peneliti selanjutnya yang melakukan penelitian serupa diharapkan menambah variabel corporate governance dengan pengukuran yang lain, sehingga pengaruh variabel $Y$ dapat lebih besar lagi.

\section{DAFTAR PUSTAKA}


Basuki, A. Tri \& N. Prawoto. (2016). Analisis Regresi dalam Penelitian Ekonomi \& Bisnis (edisi pert). Raja Grafindo Persada.

Darman. (2015). Agency Theory. Retrieved from http://theorykeuangandaerah.blogspot.co $\mathrm{m} / 2015 / 12 /$ agency-theory.html

Darwis, H. (2009). Corporate Governance Terhadap Kinerja Perusahaan. Jurnal Keuangan Dan Perbankan, 13(3), 418-430. Hidayat, A. (2013). Uji Normalitas Pada Regresi Linier Berganda. Statistikian.Com. Retrieved from https;//www.google.com /amp/s/www.statistikian.com/2013/06/n ormalitas-pada-regresi-linierberganda.htm I\%3Famp

Istiana, T., Hasiolan, L. B., \& Azis, F. (2018). Analisis Pengaruh Penerapan Struktur Good Corporate Governance terhadap Kinerja Perusahaan. Journal of Management, 4(4), 1-26.

Kusnadi, E. (2009). Analisis Regresidengan SPSS. Eriskusniadi.Com. Retrieved from https;//eriskusniadicom.cdn.ampproject.o $\mathrm{rg} / \mathrm{v} / \mathrm{s} /$ eriskusnadi.com/2009/12/12/analsi s-regresi-dengan-spss/amp?amp

Kustiani, S., Mulyatini, N., \& Lestari, M. N. (2019). PENGARUH GOOD CORPORATE GOVERNANCE DAN LEVERAGE TERHADAP KINERJA KEUANGAN (Suatu Studi pada PT. Gudang Garam Tbk yang terdaftar di Bursa Efek Indonesia Periode 2007-2017). Business Management and Enterpreneurship Journal, 1(September), 125-140.
M. Nasrum. (n.d.). Corporate Governance. Osf.Io. Retrieved March 12, 2020, from https://www.google.com/url?sa=t\&rct=j\& $q=\& e s r c=s \&$ source $=$ web\& $c d=1 \& v e d=2 a h U$ KEwi4h4Kig6HoAhUU_XMBHbaZAewQFjA AegQ|BhAB\&url=https\%3A\%2F\%2Fosf.io\% 2Ftue8a\%2Fdownload\&usg=AOvVaw1u60 G4omK7Fc6HoTlzSZGI

Melia Agustina Tertius dan Yulius Jogi Christiawan, SE., M.Si, A. (2015). Pengaruh Good Corporate Governance terhadap Kinerja Perusahaan pada Sektor Keuangan. Business Accounting Review Journal, 3(1), 223-232. Retrieved from https://doi.org/ 10.17509/jaset.v1i1.8907

Muchtar, S. \& E. D. (2013). Pengaruh Corporate Governance Terhadap Kinerja Perusahaan Manufaktur Yang Terdaftar Di Bursa Efek Indonesia. Finance and Banking Journal, 15(2), 139-159. Retrieved from https://doi.org/10.1016/B978-0-12-3739 3 $2-2.00098-3$

Nofiani, F., \& Nurmayanti, P. (2010). Pengaruh Penerapan Corporate Governance Terhadap Kinerja Keuangan Perusahaan. Pebkis Jurnal, 2(1), 208-217.

Nofitasari, N. (2015). PENGARUH GOOD CORPORATE GOVERNANCE DAN KINERJA PERUSAHAAN TERHADAP NILAI PERUSAHAAN (Studi Pada Badan Usaha Milik Negara Yang Terdaftar Di Bursa Efek Indonesia Tahun 2010-2013). Jurnal AdministrasiBisnis, 25(1).

Purnomo, R. A. (2017). Analisis Statistik Ekonomi 
dan Bisnis dengan SPSS (P. C. Ambarwati (ed.); Cetakan Ke). Cv. Wade Group.

Raharjo, S. (2014). Cara Melakukan Uji T Parsial dalam analisis Regresi dengan SPSS. SPSS Indonesia. Retrieved from https://www. spssindonesia.com/2014/02/cara-mudahmelakukan-uji-t-dengan-spss.html?m=1

Raharjo, S. (2016). Cara Melakukan Uji F Simultan dalam Analisis Regresi Linier Berganda. SPSS Indonesia. Retrieved from https;//www.spssindonesia.com/2016/08/ cara-melakukan-uji-f-simultandlam.html $? \mathrm{~m}=1$

RB. Wiyarsi. (2012). Teori Keagenan. Eprint.Ums.Ac.Id. Retrieved from https://www.google.com/url?sa=t\&rct=j\& $q=\& e s r c=s \&$ source $=w e b \& c d=3 \& c a d=r j a \& u$ act $=8 \&$ ved $=2$ ahUKEwjytuDoi6HoAhXV63
MBHazxDPcQFjACegQIARAB\&url=http\%3A \%2F\%2Feprints.ums.ac.id\%2F18221\%2F3 \%2F04._BAB_II.pdf\&usg=AOvVaw2CnPDQ NwGwOp4UnaPLIGO7

Sobirin, A. (2014). Konsep Dasar Kinerja dan Manajemen Kinerja. Repository.Ut.Ac.Id. Retrieved from https://www.google.com / url? sa=t\&rct=j\&q=\&esrc=s\&source=web $\& c d=3 \& c a d=r j a \&$ uact $=8 \&$ ved $=2$ ahUKEwi3 n9q_iaHoAhVF_XMBHaCJBBoQFjACegQIB BAB\&url=http\%3A\%2F\%2Frepository.ut.ac .id\%2F3839\%2F1\%2FEKMA5320-M1.pdf\& usg=AOvVaw08r8WBZFpN63uuU6hu2ITe Tommy Gunawan, F. S. (2018). Pengaruh Good Corporate Governance dan Ukuran Perusahaan Terhadap Kinerja Keuangan. Skripsi Universitas Diponegoro, 1(1), 253265. 